\title{
JUDEUS E CONVERSOS CASTELHANOS EM PORTUGAL
}

\author{
MARÍA JOSÉ P. FERRO TAVARES \\ Universidad de Nova de Lisboa
}

A mobilidade dos judeus é conhecida desde o início da sua Diáspora. No entanto, razões de ordem económica e, sobretudo, sócio-religiosa, como as perseguições e expulsões que sofreram durante a Idade Média, com maior acentuação nos séculos XIV e XV, fizeram com que esta minoria religiosa, tolerada entre os cristãos se visse obrigada a emigrar para regiões mais favoráveis: cidades italianas, Península Ibérica e norte de África. Porém, durante a centúria de trezentos, o nordeste e o centro hispânico foram também fustigados pelo vendaval antisemita, quer por ocasião da peste negra (1), quer posteriormente por acção das pregações de Vicente Ferrer e outros (2). A morte ou a conversão eram os dois gritos que se faziam ouvir. Nestes tempos conturbados, Portugal devia parecer aos perseguidos ou aos convertidos pela força, um paraíso, devido à quase ausência de levantamentos populares antijudaicos (3).

Esta conjuntura peninsular seria acompanhada em Portugal por um agravamento legislativo da separação entre cristãos e judeus. As ordenações visando o encerramento destes em bairros, o uso de sinal, a proibição de circularem nas zoas cristãs, após o toque das Avé Marias foram de novo promulgadas e confirmadas por D. João I (4). Amador de los Rios falou de intolerância e de perseguição aos judeus durante os reinados de D. João 1 e D. Duarte (5). Não cremos que a sua leitura esteja correcta. Se estas medidas respondiam às necessidades internas do reino, saído de uma guerra pela independência que levara a uma nova família reinante, e à imigração de judeus e conversos peninsulares, elas acabavam efectivamente por se traduzir numa protecção real por parte do soberano para com a minoria judaica, ante o aumento de tensão nas relações dos cristãos com este 
Pouco sabemos sobre o impacto que a entrada desta primeira vaga de judeus e conversos foragidos provocou no reino. Certamente que o seu número não seria suficiente para desestabilizar a sociedad cristã e romper o equilíbrio entre esta e a minoria judaica, residente no reino, como viria a suceder nos finais de quatrocentos. Não nos consta que ocorressem tentativas de uniões populares. Apenas a legislação nos permite ver uma certa tensão social que iria exigir a restrição de poder para os judeus. Estes deveriam obedecer e não, ser obedecidos. Era o cerceio do domínio social e económico que os procuradores dos concelhos exigiam nas cortes, ao que o soberano respondia com a limitação das actividades da minoria judaica, na cristandade e com a sua marginalização física o espacial. «Tendo subjacente um antagonismo religioso, comum a todo o mundo cristão, o ódio ao judeu traduz-se em Portugal, pelo que conseguimos apurar, aos níveis do poder e da economia e não dentro do espírito de intolerância e fanatismo religioso que promove os levantamentos ocorridos no resto de Península, nesta época» (6).

Era óbvio que este cerceio de poder não atentava tanto nos judeus, naturais do reino, donde sobressaíam como cortesãos umas escassas duas famílias: os Negro (Ibn Yahia) e os Navarro, estes últimos provavelmente imigrantes dos meados de trezentos e cujo nome de família foi esquecido e substituído pelo novo, de origem toponímica. O receio dos procuradores dos concelhos e, sobretudo, de Lisboa, iria certamente para os novos recém-vindos que ameaçavam ser perigosos concorrentes na economia nacional e no poder, pela sua aproximação da corte. Alguns trariam atrás de si o prestígio de um nome e a riqueza, como os Abravanel.

Por isso mesmo, como forma de ataque aos prófugos castelhanos, os cristãos utilizavam a arma de denúncia por relapsismo, alegando que tinham sido baptizados no reino vizinho e aqui se tornavam judeus (7). D. João I não tomaria qualquer medida contra aqueles que, tendo sido forçados à conversão, aqui voltavam ao seu nome judaico e a viver como crentes na Lei (8); pelo contrário, em 1392, publicar-se-iam as bulas papais de protecção aos judeus e prohibir-se-ia a conversão forçada ( $(9)$. A pesar destas medidas, aquele soberano apelaria à conversão livre, concedendo amplos privilègios aos que abjurassem a fé mosaica (10).

Seria, a partir dos finais do século XIV, que a imigração de judeus castelhanos em Portugal se tornaria mais notada, a través de permanência dos topónimos de origem, na onomástica judaica. Toledano, de Leão, de Ávila, Castelão, Burgalês, Villadiego, Segoviano, etc. acrescentavam-se a outros topónimos, transformados em nome de familia como Franco, Navarro, Saragocim, Valencim, Carmonim, de Narbona, Aragonês, Catalão, etc. 
Em raríssimos casos permaneceu o nome judaico. Conhecemos os Abravanel, provenientes de Sevilha, e talvez tivessem tido origem no reino vizinho os Latam e os Palaçano. Curiosamente estas três famílias, juntamente com os Negro, judeus cortesãos de origem portuguesa, iriam deter nas suas mãos o grande comércio com ligação à Europa e à África, as rendas reais, além de estarem próximo da corte e da família de Avis. O seu poder e prestígio reflectiase na comuna de Lisboa à qual todos pertenciam e onde exerciam cargos importantes.

Os Abravanel deviam ter entrado em Portugal na primeira década de quatrocentos. A mais antigua referência documental que conhecemos, encontrase no testamento do infante D. Fernando, filho de D. João I. Por ele sabemos que este príncipe era devedor de 52.000 reais a um Abravanel (11).

Juan Sánchez de Sevilha, ex-Samuel Abravanel, fora forçado a baptizarse nos levantamentos de Sevilha de 1391. Segundo Netanyahu teria, por volta de 1414, fugido para Portugal, juntamente com os filhos (12). Se a sua estadia no reino não deixou qualquer marca perceptível na documentação, o mesmo já não sucedeu com seu filho Juda e outros dois indivíduos, provavelmente irmãos deste: José e Ya (13). Juda seria referido, entre 1446-49, como mercador, rendeiro e tratador das moradias reais, enquanto José apareceria a aforar uma casa na rua do Picoto, na judiaria grande de Lisboa (14). Por outro lado, um documento de 1441 mencionava um Judas Bravane, um José Bravane e um Ya Bravane a residir em Lisboa (15).

A genealogia conhecida, publicada pela Encyclopaedia Judaica (16), está incompleta e não nos ajuda muito a conhecer os vários romanos desta família, talvez a mais célebre do século Xv peninsular, pela sua multifacetada incidência nos campos político, económico e cultural. No entanto, a escassez das informações só nos permite levantar uma hipotética árvore genealógica, nem sempre concordante com a obra atrás mencionada. A repetição dos nomes próprios, o silêncio sobre as mulheres, a rara indicação de filiação, sempre referida pela linha masculina, os casamentos endogâmicos que caracterizavam não só esta, mas a generalidade das mais importantes famílias judaicas portuguesas, dificultam-nos muito seguir, hoje a evolução dos Abravanel, que ainda seriam encontrados, com nome cristão, no século XVI (17).

Desde o seu aparecimiento, na história portuguesa, os encontramos ligados à família real. Por isso e, pelos privilégios com que viriam a ser agraciados, podemos considerá-los judeus cortesãos. Como tais seriam definidos, em 1455, Judas e Samuel Abravanel (18), Isaac, em 1463 e 1479 (19) e Ya, 
em 1480 (20). Todos eles eram «servidores» de D. Alfonso $V$ e Isaac acrescentava a este o ser também «servidor» do duque de Bragança (21).

Os privilégios concedidos eram coincidentes com o seu estatuto social. Samuel Abravanel, em 1453, ficava isento do pagamento dos direitos reais que todos os judeus do reino deviam pagar ao soberano, e podia fazer-se transportar em besta muar com sela e freio e com armas (22). Dois anos mais tarde, além destes, $D$. Afonso $V$ outorgava-the as isenções de pagamento de pedidos e empréstimos ao rei, da paga dos impostos à comuna, do serviço de aposentadoria e do uso do sinal distintivo, além da permissão de pousar entre os cristãos (23). Em 1463, foi a vez de Isaac Abravanel (24) e, em 1472, de Ya Abravanel, o moço (25). Mais do que as isenções, certamente importantes eram-no as distinções de carácter social, como a permissão de se transportarem em mula com sela e freio e de usarem armas, as quais thes conferiam o estatuto social de cavaleiros.

Alguns membros desta família desempeharam cargos na comuna de Lisboa, como José Abravanel, homem bom da câmara de vereação, no ano de 1464 (26).

Participaram activamente na economia do reino, quer como capitalistas, através de sociedades que firmaram com mercadores italianos e flamengos, sitos em Lisboa, quer como mercadores-banqueiros do rei e da casa de Bragança, quer inclusivamente como proprietários rurais.

Em data difícil de determinar, mas certamente dos finais da primeira metade de quatrocentos, dois judeus, Catalão e Abravanel, apresentavam a D. Alfonso $V$ uns «conselhos» sobre economia política, como hoje diriamos. Aí se explanavam considerções sobre mercantilismo comercial, a guerra monetária entre Portugal e Castela, o lavramento abundante de boa moeda de ouro e de prata, a relaão entre a má moeda e o aumento do custo de vida, a defesa da exportação de mercadorias nacionais contra a fuga da moeda e dos metais preciosos, etc. Propunham ao jovem soberano medidas atinentes a evitar a drenagem dos reais brancos de bolhão para Castela e outros lugares, e criticavam as emissões de reais pretos, demasiado dispendiosas para o erário régio, devido à carestia do cobre. Defendiam a paridade entre os escudos portugueses e as dobras castelhanas, estas sempre um pouco mais elevadas que aqueles, apesar do mesmo toque e peso das duas espécies. Condenavam as cunhagens excessivas de moedas subsidiárias, diminuindoas na proporão directa do valor dos submultiplos existentes em circulação. Referiam a necessidade de proibir a exportação de moeda e metais preciosos, assim como a limitação de determindas profissões a estrangeiros, quer 
como mercadores e cambiadores, quer como ourives, entregando o seu exercício apenas a naturais do reino. Advogavam o justo preço das mercadorias e bens necessários e alegavam que «toda franqueza he chamada gouernança e regimento de boa justiça a quall he dar a cada hũa cousa seu merecer e dar ao omen o que he pera os omens uiverem em regra de grande fartura e riqueza fora de toda mingoa e pobreza que he catiueyro contra franqueza: $E$ asy todos sendo avonddos he força senhor vos serdes riquo»... (27)

Catalão e Abravanel, ao defenderem os interesses dos naturais do reino, assumiam-se como tal e tentavam irradiar da concorência os mercadores italianos, os mais sérios rivais desta burguesia judaica. Quando ñão o conseguiam, associavam-se a eles...

Em 1475, Afonso Rodrigues, estudante em Perúsia, tinha uma conta de 200 ducados de câmara, em Florença, creditada por Isaac Abravanel e mestre Latam, por intermédio de Bartolomeu Marchione (28).

Desde 1446, encontramos sociedades de mercadores-banqueiros a arrematarem os pagamentos das tenças aos moradores da casa real. Entre este ano e 1454, Judas Abravanel associou-se a João Dias Beleágua, Leonardo e Marco Lomelino (29).

Mercadores, estes judeus aumentavam o seu capital com a arrematação das rendas, contratos e monopólios reais. Isaac Abravanel e Moisés Latam obtinham, em 1477, o contrato das 200.000 coroas dos casamentos da casa real (30). Ya Abravanel teve, nos anos de 1477-1480, o contrato das moradias da casa de D. Diogo, duque de Viseu (31). Aliás seriam as dívidas para com estes judeus, por parte do duque que levariam um descendente destes, cristão, Henrique Fernandes Abravanel, a receber de D. Manuel 800.000 reais, como herdeiro que era de Ya Abravanel, seu avô, e de Juda Abravanel, seu tio (32).

Samuel Abravanel e seu filho José, genro de Isaac Abravanel, participaram no comércio do açúcar da Madeira com a Europa. Pela carta de perdão de Benvinda, viúva daquele, sabemos que «por nossa parte (de D. João II) foy enbargada toda a fazenda, beens que se tratava e nomeava em nome de Yoçe Abravanell e asy a que ficou em pose e cabeca de casall Bemvinda, sua (de Samuel) molher, o quall enbarguo the asy foy posto por çertas auções, rrazões que hii avia pera ello, s., por se dizer que o dito Yuçee Abrabanell e Jaco Abravanell, seus filhos, que ora sam lancados em Castella, eram herdeiros da dicta fazenda $e$ allem de asy serem herdeiros aviam per ella seus casamentos e que por serem sabedores e partyçipantes na treiçam do duque de Viseu, perdiam pera nos toda sua erança e tanbem que por o dicto 
Samuel Abravanell em sendo vyvo e ella, dicta Bemvinda, saberem parte da fazemda que aos dictos seus filhos pertençia e asy de alguũa fazemda de Isaque Abravanell e todo callaram e encobriram sem enbarquo dos pregões, pennas de perdimento de beens que forom postas a quem ho nom descubrisse. $E$ asy por se dizer que o dicto Isaque Abrabairell e os dictos seus filhos serem lançados em Castella, o dicto Samuell Abrabanell e ella, Bemvinda, sua molher, enviarom ouro, prata, joyas, dinheiros, cartas e rrecados aos sobredictos e rreceberam outros rrecados delles sem enbarguo de nossas defessas, penas que sobre ello eram postas. $E$ ora ha dicta Bemvinda por sy e pr seus filhos que ora neste rregnno tem, nos pidio por merçe que ouvesemos piadade com elles e nos prouvese reçebermos em serviço huũ milhãao de rreaes por todallas ditas suas fazendas allem de todo ho acuquar, dinheiros e cousas que nos atee agora teemos tomadas, avidas e despesas do dicto Juçe Abrabanell, asy na ilha da Madeira como em estes rregnnos e em quaesquer outras partes...» (33)

O trato da vintena da Guiné coube a Juda Abravanel, durante os anos de $1482-83$ (34)

Foram igualmente banqueiros do rei e da família real. Já referimos o caso de um Abravanel, credor do infante D. Fernando, morto em Fez. Pela carta de quitação de João Afonso, tesoureiro da casa de moeda de Lisboa, sabemos que Isaac Abravanel recebeu 200 mil reais, quantia que emprestara a D. Afonso $V$ para pagamento de 1.500 ducados, em Roma (35). Mais tarde, surgiria como financiador da infanta $D$. Beatriz que lhe pagaria a dívida com a concessão do arrendamento das rendas da ordem de Cristo (36).

A ligação dos Abravanell com a casa de Bragança de Viseu fá-los-ia cair em desgraça junto a $D$. João II e fugir para Castela, terra dos seus antepassados. Entre as acusações feitas a Isaac Abravanel, encontravam-se as de financiar as conjuras contra o rei, por parte dos diques de Bragança e de Viseu. Pelas sentenças de D. Gutierres Coutinho, de Isaac e de seu genro, José, filho de Samuel Abravanel, sabemos que o crédito para pagamento de homens e armas orçava os 20.000 cruzados de ouro, ou seja, 9.500 .000 reais, além da possibilidade de movimentar cerca de 38 milhões de reais (37).

A sua riqueza e privaticidade com a corte transpareciam na própria sentença de Isaac Abravanel: «por o dito Reeo seer muito gramde servidor e amigo dos ditos dom Fernando e dom Joham, e de toda sua casa, e por seer homẽ mui rico, e muy afazemdado, e entemdido, e industrioso, averido isso meesmo os sobre ditos mester dinheiro, que pera a dita maldade e traiçam aviam mester, Ihe vieram a descobrir o dito trauto, treiçam e maldade, que contra 
nos tiinham trautado e hordenado, mamdandolhe que sse viesse a nossa corte, e o que sentisse que contra elles se fazila e dezia os avisasse e tho escprevesse..." (38)

O impacto da sua fortuna e o seu prestígio na sociedade portuguesa tornaram-nos imortais nos versos do Cancioneiro Geral, para já não falarmos de Isaac e de seu filho Juda, o célebre Leão Hebreu, na cultura europeia da quatrocentos e de quinhentos:

"estes sam os do cuydar

sem o poderdes neguar

os mores oyto senhores.

Sera primeyro Latam,

o segundo Samuel,

o terceyro Salamam

o quarto sera Fayam

o quinto Abrauanel.

«Namorado he Palaçano

Gualyte, tambem Jaçee, poys que cuydam todo ãno, mas cuydã em dar seu pãno

mays do que val ala fe.

Cuydam no arrendamento, quando cuydam demcampar

E cuydam quee perdimento, quando cuydam que por çento

trinta he pouco ganhar» (39)

Os Abravanel não foram os únicos imigrantes castelhanos que a documentação portuguesa refere. Mais difícil de destrinçar, na sua mobilidade, seriam os Caro, os Benveniste, os Abeacaar, os Abenazo, os Alhaquim, os Abet, os ben Adret, os Abopa, os Barzelai, os Benarroio, etc., cujos nomes de família deveriam ser comuns a toda a Península. Outros poderão ser detectados mais facilmente, quer como servidores dos reis de Portugal, quer como mesteirais da corte, quer como magistrados nas comunas. A onomástica com base nos topónimos, permite-nos localizá-los por todo o reino, perfeitamente integrados na sua nova pátria adoptiva (40)

Jacob Castelão, servidor de D. Afonso V, optou por residir em Braga. Em 1443, recebia uma carta de privilégio que o isentava do pagamento dos direitos reais, dos impostos e serviços à comuna, de aposentadoria e the permitia andar em besta muar (41). Em 1450, por nova carta, os serviços à co- 
muna eram sustituídos pela isenção do pagament de pedidos e empréstimos ao rei (42).

Moisés Castelão residia em Montalegre e obteria também daquele soberano a isenão do exercício de cargos na comuna, cio serviço de aposentadoria e recebia autorização para usar armas e pousar entre os cristãos (43). A um homónimo deste, morador no Porto, servidor de $D$. Afonso $V$, era concedida a permissão para andar em mula (44) e para colocar nos portais e janelas de sua casa, um castelo e um alão, como brasão (45).

Mestre Samuel Verdugo, natural de Castela, veio residir para Elvas onde se dedicaria ao fabrico das armas, pelo que obteria a protecção do rei e do concelho (46). O mesmo sucederia com Salomão Ardutel, alfaiate (47) e com Abraão Cençarrado (48) que optariam por Lisboa, ou com m Abraão Cabanas, físico, natural de San Felices, que viria casar a Gouveia (49).

Moisés Franco, natural de Valladolid, e radicado em Portugal, obteria permissão para casar com Estrela, judia portuguesa, depois de ter apresentado um documento de divórcio de su primeira mulher que permanecera em Castela (50). Mestre Moisés Abarrizo, cirurgião, morador em Messejana, receberia autorização de $\mathrm{D}$. João II para poder vender, pelo reino, pano de Castela a retalho, pois era judeu castelhao radicado em Portugal pelo casamento e pela sua família (51).

A segunda metade do século XV tornaria a conhecer períodos de verdadeiro terror, quer contra os judeus, quer contra os conversos, como o que ocorreu em Toledo, em 1449. Estes momentos críticos levavam à partida das duas minorias para outros lugares, onde o antisemitismo não fosse tão agressivo. Portugal perfilharia as simpatias de ambas. Talvez por isso, alguns defenderiam uma posição pró-portuguesa, contra os Reis Católicos, como rabi Jacob ou alguns conversos de Ciudad Real (52).

As últimas décadas de quatrocentos conheceriam o agravamento das relações entre cristãos e judeus e cristãos e conversos, estes acusados de heresia criptojudaízante. Para prevenir ao aumento de tensão, Isabel e Fernando optariam por expulsões pontuais, como as dos judeus de Andaluzia, antes de se decidirem pela expulsão geral, ordenada em 1492. Sevilha, Bilbau, Trujillo, Ávila, etc. foram achas numa imensa fogueira que a entrada da Inquisição agravaria.

Todo este clima adverso à vida das comunas levaria à saída paulatina dos seus membros. Conversos e judeus abandonavam Castela e optavam 
por residir temporária ou definitivamente noutros lugares da Península, da Europa ou de África. Portugal foi o reino peninsular que mais afectado acabaria por ser, pois, à entrada pontual de uma ou outra família, acabaria por suceder a entrada em massa de judeus, com a expulção de 1492, e com eles a de conversos judaízantes.

A sua vinda desorganizaria o precário equilibrio existente nas relações entre as comunas portuguesas e a maioria cristã, o qual se vinha deteriorando desde o terceiro quartel de quatrocentos. O medo contra hipotéticas concorrências profissionais por parte dos adventícios, agravado pelos surtos epidémicos e pelas superstições que viam nestes o castigo dos pecados, instalaou-se, quer entre a minoria judaica, natural do reino, quer entre os cristãos e provocaria o ruir rápido de um entendimiento de séculos.

Da luta de interesses que, há muito, se vinha fazendo ouvir nas vozes dos procuradores às cortes, à perseguição ao herege e reflexamente ao judeu, iria um passo. D. João Il, sob cujo governo, a crise iria rebentar, usaria uma política férrea, extremamente legalista de protecção às comunas contra as uniões cristãs, sacrificando para tal os conversos e os judeus castelhanos.

As vagas de individuos, fugitivos à acusação de hereges e à Inquisição castelhana, na sua maioria em trânsito para outras paragens, geravam, nas principais cidades do reino, como Lisboa e Porto, uma onda de ódio aos conversos. Em 1485, este concelho recusava-se a recebê-los, alegando que «sam estrangeiros e daquella casta de que hy ha sospeicam" (53). Dois anos mais tarde, com o pretexto de que residiam aqui muitos estrangeiros, a câmara decidiria dar-lhes o prazo de três dias para saírem da cidade (54). O objectivo era a irradiação dos conversos castelhanos, tal como ocoria noutros lugares do reino (55). D. João II cortaria cerce estas exorbitâncias, mas dar-lhesia razão ao criar os primeiros inquisidores, «rrelligiossos e pesoas outras que pellas comarcas do regno honde os dictos marranos estam, vaão saber e se enfformar de como vivem e viveram atee qui pera os que se achar que nom sam boons christaãos averem aquella condenaçam que por tall caso merecem» (56). Nos primeiros dias de Abril de 1487, sob a alçada dos bispos das várias sés do reino, começaram a actuar os primeiros inquisidores portugueses. Ao mesmo tempo, o soberano proibia, sob pena de morte, a saida do reino de todos os castelhanos, a fim de que as investigações iniciadas pudessem ser completadas e devidamente castigados o relapsos. No entanto, esta medida viria a ser levantada por demasiado lesiva dos interesses dos naturais de Castela que não eram conversos (57).

Portugal começava a ser palco de autos da fe, mesmo sem a presença da Inquisição. Embora as notícias sejam escassas, os cronistas já se referi- 
ram vagamente a elas (58). Em Santarém, João de Niébla era queimado por judaízar em casa de um Arondim, ourives, com quem festejara a Páscoa das Cabanas (59). Já anteriormente, em 1485, Lisboa tinha sido abalada por levantamentos populares que se seguiram à prisão de um converso castelhao (60).

A 2 de Outubro de 1488, don João Il tentaria cortar pela raíz o problema dos criptojudaízantes castelhanos, para evitar que Portugal se transformasse na fogueira que era o reino vizinho. Assim, promulgaria a proibição de estes entrarem no reino, sob pena de serem entregues aos oficiais de justiça dos Reis Católicos (61). Por fim, nesse mesmo mês, ordenaria a saída de todos os que não estivessem sob a alçada dos inquisidores, para outras zonas da Europa, vedando-Ihes o norte de África (62). No entanto alguns decidiriam embarcar clandestinamente para esta região, a fim de mais facilmente poderem retornar à fé de origem. Sobre os desrespeitadores da proibição régia, mestres e donos das caravelas transportadoras dos «marranos» e dos seus haveres caia dura a justiça real: perda da vida e confisco dos bens, incluindo os barcos, para a coroa (63).

Más a grande debandada dar-se-ia com a publicação do édito de expulsão de todos os judeus de Espanha, em Março de 1492. A partida fazia-se penosamente: era uma nova diáspora que se iniciava e que muitos interpretavam como o castigo de Deus pelos pecados cometidos pelo seu povo, remontando-os à adoração do bezerro de ouro. A necessidade de vender os bens em prazo tão curto, três meses apenas, acarretaria obviamente a depreciação das propiedades e das mercadorias que a legislação proibia exportar como ouro, prata, moedas, armas, cereais, etc. O caminho era duro e sem regresso para muitos. Se, em Castela, uns cristãos os ajudavam, como alguns cavaleiros e oficiais das comarcas fronteiriças, em troca de uma parte da fazenda que os expulsos levavam, como os de Cáceres e Arroyo el Puerco (64), outros exigiam-lhes portagens e impostos ilegais, como em Fresno de los Anjos, Cidade Rodrigo (65) e no caminho que ia de Bobeda para Samora (66), e outros ainda, matavam-nos para os roubar, como o assassinato de judeus que vinham para Portugal, nos arredores de Placência (67).

Este reino fora, de facto, a nova pátria escolhida por uns e aceite pelo soberano, ou um mero local de passagem para outros lugares. Contra a maioria do seu conselho, don João 'I responderia favoravelmente aos representantes dos judeus castelhanos, autorizando a entranda e permanência no reino, de um certo número de famílias. Desconhecemos ao certo quantos entraram, quer oficial, quer clandestinamente, par aqui se fixarem ou para utilizarem Portugal como lugar de trânsito para o norte de África ou para o Levante me- 
diterrânico. Em contrapartida, o monarca procurava obter dinheiro para a cruzada contra os mouros e experientes profissionais de certas artes, ligadas à actividade bélica.

Os cronistas não coincidem nas informações que nos transmitem. Rui de Pina preocupou-se mais em assinalar o parecer desfavorável dos conselheiros e a reacção contrária dos povos, perante a entrada dos judeus castelhanos a qual viria acompanhada pela peste. Estes teriam oito meses para abandonar o reino, sob pena de ficarem cativos para coroa. O rei comprometia-se a colocar barcos à disposição dos que se encontravam de passagem (68).

Garcia de Resende limitar-se-ia a relatar a versão oficial, sem fazer eco da oposição do conselho nem dos povos. Segundo ele, o cativeiro seria apenas para os que tivessem entrado clandestinamente no reino (69).

O cômputo apresentado pelos contemporâneos seria bastante díspar. Damião de Góis escrevia que entraram em Portugal mais de 20000 casais, alguns com dez e doze pessoas, o que somaria mais de 100000 indivíduos (70). Abraão Zacuto mencionaria 120000 judeus castelhanos aqui imigrados (71). Segundo aquele cronista, destes uns pagavam oito cruzados per capita, excepto as crianças de colo cuja entrada não fora taxada, e os mesteirais de arte do ferro que entregavam metade daquele valor, no caso de cá quererem ficar (72).

Samuel Usque falaria do imposto de dois escudos que os adventícios pagariam, enquanto Jerónimo Osório referida oito escudos (73).

Os cronistas espanhóis indicar-nos-iam cerca de cem mil, os judeus que teriam entrado em Portugal (74).

Aboab, um século mais tarde, confirmaria a entrada das 600 «casas» que permaneceriam em Portugal. O Porto receberia trinta famílias que se fixariam na rua de $\mathrm{S}$. Miguel (75).

Don João II, ao autorizar a entrada dos judeus castelhanos, limitou-lhes os portos de entrada no reino. Segundo os cronistas espanhóis, estes seriam: Bragança, Miranda, Vilar Formoso, Marvão e Eivas (76). A estes lugares de recepção, onde se encontravam os recebedores do rei, correspondiam os lugares fronteiriços castelhanos de Puebla de Sanabria, San Felices de los Gallegos, Ciudad Rodrigo, Valência de Alcântara e Badajoz (77).

Os oficiais castelhanos vigiavam para que os emigrantes não saissem de Castela com mercadorias defesas, no que eram auxiliados por alguns cristãos, certamente em troca de alguns bens dos judeus: «Sepades que a nos 
es fecha relaçion que de tres meses a esta parte diz que algunos judios de los que biven en las villas de Caçeres e Arroyo el Puerco e en otros lugares de la comarca han sacado fuera de nuestros reynos para el reyno de Portugal y para otras partes, oro e plata e moneda amonedada y que algunos caballeros de las dichas villas e sus comarcas les han dado para ello ayuda e consejo y les han favoresçido" (78). Os portugueses fiscalizavam as entradas, interrogavam sobre os lugares de proveniência por causa da peste e colectavam o tributo para a permanência ou a passagem pelo reino. No entanto, muitas familias judaicas passariam clandestinamente a fronteira.

Como de costume, a documentação não é abundante em informações sobre o total de dinheiro e de pessoas entradas no reino. Pelas cartas de quitação dos recebedores, podemos distinguir três qualidades de judeus castelhanos:

- os judeus das 600 «casas» que viriam a ser tributados em 8 cruzados de ouro e distribuidos por Lisboa, Évora, Porto e Coimbra;

- os judeus em trânsito, taxados também em 8 cruzados, por cabeça;

- e os mesteirais do ferro, colectados em 4 cruzados.

Pela carta de quitação, dada por don Manuel a Fernando Afonso, sabemos que este recebeu, em Lisboa, 8390220 reais dos judeus castelhanos (79).

João Mendes Cicioso, recebedor em Évora, ficou quite da soma de 8 951312 reais, distribuida por:

- 5106169 reais e meio dos judeus das 600 «casas»;

- 3610618 reais e meio dos judeus taxados a 8 cruzados por cabeça;

- 187590 reais dos ferreiros e latoeiros inscritos, à razão de 4 cruzados cada;

46935 reais, entregues por Antão de Gigueiredo, recebedor-mor destes dinheiros na corte (80).

Pela quitação de João Álvares de Almada, sucessor deste no cargo de recebedor-mor da capitação dos judeus castelhanos na corte, sabemos que entraram no cofre 26356957 reais, assim repartidos:

- 3183961 reais de Fernando Afonso, recebedor em Lisboa do dinheiro das 600 «casas", a 8 cruzados;

- 751000 reais de Pedro Pessoa, recebedor das mercadorias dos ditos judeus; 
- 2605420 reais de João Brandão, colector da capitação das 600 «casas" no Porto;

- 59280 reais de João Bispo, recebedor das taxas dos ferreiros e latoeiros;

- 1604110 reais de Afonso Gonçalves, encarregado de receber o dinheiro das 600 «casas» em Coimbra;

- 6439610 reais de João Mendes Cicioso, recebedor das 600 "casas» em Évora;

- 244252 reais de João Gonçalves Batavias, recebedor do Algarve;

- 3885000 reais de Antão de Figueiredo, antecessor de João Álvares, no cargo de recebedor;

- 92038 reais de Afonso Vasques, cobrador da taxa na porto de Marvão;

- 4578000 reais, pagos pelas comunas dos judeus «pollo perdam das recadações»;

- 1130000 reais, entregues pelso judeus castelhanos, como parte do pagamento do dito perdão;

- 11700 reais de alguns judeus de 8 cruzados;

- 4080 reais de mestre Jacob (81).

As cartas de quitação acabadas de referir permitem-nos extrair algumas conclusões sobre a tributação que recaiu sobre os judeus castelhanos que entraram legalmente em Portugal. Assim, temos que:

- 8 cruzados foi a capitação paga por todos os judeus de maioridade, quer os designados das 600 "casas" que aqui permanéceriam, quer os que se encontravam de passagem para outros lugares, com excepção dos mesteirais do ferro, que pagavam metade;

- Sobre os bens móveis recairia uma taxa de valor desconhecido;

- Para libertar os insolventes, o soberano lançou um «perdão» general, pago pelas comunidades nacionais e pelos judeus castelhanos.

Podemos também, com uma certa cautela, tentar fazer uma estimativa sobre o número de indivíduos que entraram no reino, embora reconheçamos que ele ficará sempre aquém da realidade, atendendo ás discrepâncias apresenadas pela própria documentação e ao facto de ignorarmos completamente a quantidade de pessoas entradas pelos portos de Miranda e de Bragança 
e os imigrantes clandestinos que viriam a beneficiar da libertação dada por D. Manuel quando subiu ao trono. A outra ressalva respeita ao facto de desconhecermos se os totais apresentados indicam somente o quarto do tributo ou a sua globalidade por indivíduo.

Se partimos da hipótese de que as verbas referidas representariam o quarto da tributação individual, teriamos, pela carta do recebedor-mor da corte, um equivalente a 23.320 judeus aproximadamente. Cerca de 20.000 ter-seiam distribuido por Lisboa e Évora, os concelhos com maiores judiarias. Só a cidade alentejana deveria ter recebido um contingente que oscilaria entre os 8.256 e os 11.164 judeus, no seu máximo, além de cerca de 480 ferreiros e latoeiros (82). Dado o seu número elevado, os imigrantes não couberam nas casas do bairro judaico, devendo também distribuirem-se pelas casas dos cristãos (83). Mais tarde, após o édito de 1497 e da saída dos mouros do reino, muitos destes cristãos novos de origem castelhana iriam habitar a antiga mouraria.

D. João II tentaria afastá-los do Algarve, que só viria a receber uma parte mínima, cerca de 312 indivíduos. Procurava assin impedi-los de partir para terra mouros.

Conhecemos a existência de acampamentos fronteiriços, onde temporariamente se alojaram alguns destes judeus. Em Castelo de Vide, esteve erguido um, certamente para os que entrariam pelo porto de Marvão. segundo Velasco da Mota, oficial a quem cabia a vigilância, defesa e alçada deste arraiàl, em Setembro de 1492, encontravam-se nele entre 4.000 e 5.000 pessoas, guardadas de dia e de noite, para evitar os roubos e raptos feitos pelos castelhanos, durante as suas surtidas em território português (84). Em Vila Flor de Trás-os-Montes teria tido lugar outro desses acampamentos (85).

Os números que calculámos estão certamente aquém do número de judeus castelhanos, entrados em Portugal. Creemos, no entanto, que esse número nunca se aproximaria dos 100.000 individuos referidos pelos cronistas. No seu máximo andaria pela metade.

Embora a intenção do soberano fosse conceder residência a um número limitado de judeus, as 600 "casas», o facto é que muitos outros escolheram Portugal como local de permanência temporária. Um número indeterminado entrou clandestinamente. Sobre estes, por ñão lhes ter sido concedida autorização para aqui entrarem e sobre os que ficaram insolventes, a justiça real caiu dura: a servidão foi o seu castigo. Jacob tornou-se escravo da estrebaria real (86). Bernáldez calcularia na ordem do milhar o número de judeus castelhanos que se teriam tornado servos do rei (87). 
Para estes, D. João II publica a 19 de Outubro de 1492, uma lei tendente a atrai-los à conversão, concedendo-Ihes amplos privilégios e a possibilidade de regressarem à sua terra de origem (88).

Aos que recussaem o baptismo e estivessem na situação de devedores da coroa ou de clandestinos, o soberano mandar-lhes-ia tirar os filhos que entregaria a Álvaro de Caminha, em 1493. O seu destino seria S. Tomé, ilha atlântica que o soberano desejava povoar, além de nela sesénvolver a cultura da cana sacarina (89)

Apesar de toda a crueza de que se revestiu o acto, régio, D. João II não os deixou ao abandono, ficando o próprio capitão e donatário da ilha responsável por eles, segundo o próprio testemunho, que deixou exarado no seu testamento: «quamdo viim de Portuguall trouxe allvara del rrei dom Joham que Deus teem para a cada cimquo moços dar hũu escravo e hũua escrrava pera suas mamtemças ou os dar a quem os guovernase em quamto nom fosem pera per sy vyverem e porque niquem os podia milhor aguassalhados e curados teer que eu memcarreguey delles thomamdos em minha casa guovernados com os ditos sseus escrravos e com outros que dos del rrei pera isso thomey" (90). Apesar de caber ao so berano o vestir e a alimentação destés jovens judeus que ele baptizara e que se educavam em $\mathrm{S}$. Tomé, a verdade é que a vida ñão era fácil para ninguém e muito menos para crianças. A fome, a doença e os animais selvagens viriam a dizimar muitas delas. o próprio Álvaro de Caminha no-lo afirmaria: «muyito çedo tyve a comy disso que avya no mato e mandey moços fora pellas amgrras pera sserem mamtheudos". Aos filhos dos judeus castelhanos que sobrevivessem, deixava os bens que possuia como donatário de S. Tomé Pedro Álvares, seu familiar, que ele instituia como sucessor no cargo de capitão e donatário da ilha, ficava com a incumbência de cuidar das crianças «e saber com sam limpos castiguados e emsignados e em sseus mamtimentos e em todo ho all que pera consservaçã de suas vidas e emsinos comprir» (91).

As informações da época ñão são abunantes em nomes dos que ficaram no reino. Se uns escolheram Portugal para segunda pátria, como Salomão, Mestre, rabi Habney (92), D. Samuel, físico (93), Benveniste Calahorra (94), Meir Sornaga (95), rabi Juda Corcoz (96), mestre Moisés de Saragoça, cirurgião (97), Moisés Hen da Corunha (98), os rabis Isaac Aboab que viria a falecer no Porto (99), Sem Tob (100) e Abraão Zacuto (101), etc, outros aqui entraram para passar a África ou à Europa e outros, os de menores posibilidades económicas, para retornarem baptizados à sua terra de origem e reocuparem suas casas e bens. $O$ apelo à conversão de $D$. João II surtira o seu afeito e tivera correspondência por parte dos Reis Católicos: «Sepades 
que por parte de algunos judios estantes en el reyno de Portugal, que por nuestro mandado salieron de nuestros reynos y señorios nos es fecha relaçion que ellos, alumbrados del Espiritu Santo conosciendo el herror en que estavan se querian bolber a estos nuestros a nuestros reynos para que se convertir a nuestra Santa Fe catholica e permanesce e morir en ella como catholicos christianos e por su petiçion nos fue soplicado e pedido por merçed que para venir a estos nuestros reygnos les diesemos nuestra carta de seguro para que libre e seguramente pudiesen venir ellos con sus hijos e mugeres e faziendas" (102). A conversão significava para muitos a possivilidade de retomar a liberdade perdida, a subsistência económica e a segurança físi$\mathrm{ca}$, ante os roubos e atrocidades cometidas, quer pelos mareantes, quer pelos mouros aos que passavam ao norte de África. Receber o baptismo em Portugal ou na fronteira castelhana era a possibilidade de retornar à terra de origem, aos seus bens vendidos ao desbarato, porque despreciados com a urgência da partida, e a esperança de amanhã poder noutras paragens e por moios mais seguros, voltar à fe dos seus antepassados.

A 15 de Janeiro de 1493, os Reis Católicos outorgavam carta de segurança a D. Çague Abuacar, físico «e a todos los judios e judias que con el se tornem christianos en el dicho reyno de Portogal o en el primer logar de christianos donde entraren en nuestros reynos e trayendo fe e testimonio dello para que puedan venir libremente a estos nuestro reynos e estar a bevir en ellos. Otrosy les damos liçençias en abrayco e en aravigo con tanto que no sean libros del Talmud ni Brivia ni otros libros de la lei musayca. E mandamos a qualesquier personas a quien ellos vendieron sus bienes rayzes despues que nos les mandamos salir destos nuestros reinos que ge los tornen a restituyan pagandoles lo que por ellos les dieron con lo que mas en ello ovieren gastado e mejorado» (103).

Juda Corcos, de Samora recebia carta de segurança e de perdão por ter passado mercadorias defesas para Portugal (104). João Soares e Ferrand Nuñes, vizinhos de Fuentidueña, obtiveram permissão para retomar os seus bens, uma vez que se baptizaram em Portugal (105). Cartas idênticas seriam outorgadas a Afonso García de Badajoz, Diego de Silvera, Francisco Nieto, fernando de Alcaraz, Henrique de la Torre, João dias e João de Toro, todos de Puente del Arzobispo, Rodrigo Arias Maldonado, de Cidade Rodrigo, etc. (106).

O mês de Dezembro de 1496 tornaria a trazer o desespero aos judeus. Desta vez seria o rei de Portugal que, obedecendo às exigências da política peningular, decidiria expulsá-los do reino, após ter tido logo após a subida ao trono a atitude magnânima de dar a liberdade aos judeus castelhanos que 
ainda se encontravam em cativeiro. O prazo limite para partirem seria o mês de Outubro de 1497. Só poderiam ficar os que decidissem receber o baptismo.

No entanto, D. Manuel ñão desejava a partida de uma minoria tão importante económica e culturalmente para o país. Enquanto os mouros partiriam, sem qualquer entrave, para Castela e Äfrica, os judeus veriam erguer-se obstáculos diversos, com a finalidade os dissuadir de partor. À limitação dos portos de embarque, seguir-se-ia o baptismo forçado das crianças, começando pelas de menos idade até atingir os adolescentes. A estes seguir-se-iam os adultos obrigados a converter-se, uma vez que muito poucos conseguiriam partir dentro do prazo estabelecido pelo soberano.

Baptizados, muitos destes judeus castelhanos preferiram permanecer em Portugal a retornar a Castela, definitivamente, embora a mobilidade fosse uma das suas principais características. Tal vez que um das razões fosse a promessa de $\mathrm{D}$. Manuel de não inquirir sobre a sua religião, durante os próximos vinte anos (107).

Rabi Moisés de Palência fixar-se-ia com a sua família em Tomar, onde viria a falecer, juntamente com a esposa antes do baptismo geral. Seu filho, casado com uma judia, receberia as águas do baptismo em Lisboa, aonde se dirigira para vender alguns bens para a partida e após the terem retirado o filho único, criança de meses. Se ignoramos o nome judaico desta família, conhecemos, no entanto, o nome cristão que aquele viria a tomar: Jorge Manuel. Mercador, home rico e conceituado, manifestaria uma arrogância perante os cristão e outros correligionários de origen castelhana, de apelido Jusarte. As duas famílias viriam a ser vítimas de actuação do Tribunal do Santo Ofício, em Tomar, e a Jorge Manuel não Ihe valeria tão pouco o ter uma filha casada com um cristão velho, cavaleiro da casa real, e um filho, mestre antónio Manuel, cirurgião do mestre do convento de Cristo e inquisidor nas terras da ordem de Cristo. Jorge Manuel sairia no auto da fé de 1543, condenado por herege convicto e persistente. Os Jusarte, seus inimigos, sairiam reconciliados, embora condenados a cárcere e hábito perpétuos, com excepção do filho mais novo, nascido cirstão, Gaspar, que viria a ser queimado. O ódio e a rivalidade entre as duas famílias seria bem visível ao longo do processo de Jorge Manuel: este, orgulhoso da sua aristocracia e linhagem, da sua posição social, pois era mercador de grosso trato, enquanto os Jusarte eram simples plebeus, enriquecidos com o comércio das carnes e dos curtumes (108).

Tambén alguns familiares do rabi Abraão Seneor escolheriam Portugal para residir. A estes foi-lhes permitido mantener o apelido Coronel. Mestre 
Nicolau Coronel, físico de D. Manuel, receberia ainda o privilégio de ser feito fidalgo de solar. A sua nobilitação exigiria da parte do soberano, uma carta de limpeza de nascimento: «e lhe tiramos toda a macula que por seu naçimento ou por qualquer erro, outra cousa Ihe posa seer posta» (109). Outro Membro desta família era o cirurgião metre Francisco Coronel, morador no Porto (110).

As genealogias referenciadas nos processos das diversas inquisiçãooes permitem-nos reconstituir a biografia de alguns judeus castelhanos que aqui permaneceram. As diversas comunidades transmontanas são disso uma pequeña amostraguem. Tomemos por exemplo a cidade de Bragança:

Francisco Aires era natural de Medina del Campo. Veio para Portugal adolescente. Foi baptizado na Lousã. Viveu em Lisboa antes de ser fixar definitivamente em Bragança. Aqui vivia dos redimentos e dedicava-se à arrematação das rendas. Era um indivíduo abastado e de prestígio social, pois era escudeiro do duque de Bragança. Com cerca de 62 anos de idade seria preso pela Inquisição e acusado de criptojudaísmo, vindo a beneficiar do perdão geral de 1548, depois de ter confessado as suas culpas (111). A sua terceira mulher, a portuguesa Branca Fernandes, de 25 anos de idade, presa pela mesma altura, não viria a ter a mesma sorte. a sua confisão não foi reconhecida como suficiente, pelo que viria a ser condenada por herege e queimada em Évora, a 23 de Novembro de 1551 (112). Seu marido já não conherecia o seu trágico fim, pois entretanto falecera.

Dinis Álvares de Carvajales era tido por rabi, dentro da comunidade cristã nova. Viria a ser relaxado, em Lisboa, cerca de 1544. Seu filho, Bento de Leão, receberia a reconciliação (113). Luis Álvares, preso na Inquisição de Évora, em 1544, era igualmente natural de Castela (114), o mesmo sucedendo com Gonzçalo (115) e Manuel de Aranda (116).

Os Carriões eram naturais de Zamora. Luis do Mercado era um letrado na lei de Moisés que fora escrivão dos judeus, na comuna desta cidade. Alcoiheu-se a Bragança, onde parte dos filhos ficariam a residir, enquanto outros regressariam à terra de origem. Seus netos, Luis do Mercado e Tomé do Mercado, este último residente em Castela, viriam a ser presos pela Inquisição de Valladolid, enquanto a mãe, a anciã Beatriz Gonçalves, a «carriona» o seria pela Inquisição de Évora (117).

Álvaro Gomes era originario de Ponferrada, na Galiza (118). Diogo de Ledesma, alfaiate, era natural de Leão e estava casado com Susana de Valladolid, natural de Carmona. Ambos seriam presos pela Inquisição, vindo a beneficiar do perdão geral de 1548 (119). Diogo Neto, tosador e mercador, era 
filho de Francisco neto e de Helena Álvares, naturais de Ledesma. Seu irmão António residia em Miranda Do Duoro (120). O sapateiro Sebastião Pires era galego e à sua terra de origem se alcoheria com a entrada da Inquisição em Portugal (121).

Exemplos dessa fixação foram os apelidos de origem toponímica que aqui permaneceram: os Sória, os Valladolid, os Ledesma, etc.

Enquanto na região transmontana, os cristãos novos de origem castelhana provinham das regiões vizinhas da Galiza, Leão e Castela, continuando a mantener relações com os seus familiares que aí permaneceram ou que a esses lugares retornaram posteriormente, em Évora, por exemplo a proveniência marcante seria Castela e Andaluzia. Apenas alguns exemplos:

Beatriz Álvares, a carvoeira, casada com João de Cáceres, borzegueiro, cristão velho, segundo a mulher, era natural de Mérida (122).

O judeu Samuel, de Talavera de la Reina, entraria em Porugal em 1492. Foi baptizado em Alcoutim, no Algarve, juntamente com sua mulher, natural de Escalona. Em cristãos, tomariam os nomes de Fernão Álvares e de Guiomar Rodrigues. Dois dos seus filhos emigrariam para Goa, como soldados, outro residia em Lisboa, enquanto uma filha se encontrava casada na Beira. Preso, com cerca de 75 anos, seria condenado a abjurar de leve (123). Naquela data, entraria tambén o castelhano António Caldeirão, tecelão de pano de linho (124).

Uma família cristã nova importante seria a dos Córdovas, relacionada com gente honrada e fidalga. Constança Fernandes «Cordona», natural de SeguraCórdova, definia-se como mulher rica, honrada e virtuosa. Era casada com o converso castelhano Álvaro Gonçalves Cordão. Era tia dos Córdovas, dos quais um deles era cónego no sé de Évora (125). Alguns dos seus irmãos seriam queimados pelas inquisições de Llerena e de Toledo.

Como conclusão, podemos dizer que foi constante a presença de judeus castelhanos, em Portugal, quer devido à imigração, provocada pelos diversos levantamentos antisemitas ao longo da Idade Média, e pela expulsão de 1492, quer devido à mobilidade natural deste povo, quer ainda às relações familiares e económicas que se estableceram entre os indivíduos de um e outro reino.

Algumas destas familias viriam a distingui-se pela projecção social, económica e cultural alcançada.

O êxodo, nos finais de quatrocentos, faria de Portugal e, nomedamente de Lisboa e da sua academia, e centro único da cultura judaica peninsular. 
Para aqui seriam trazidos os mais antigos códices, como o Hil-leli, que depois seria vendido em África, segundo Abraão Zacuto (126), enquanto outros livros hebraicos tomariam o caminho da Índia (127).

Com o baptismo geral de 1497, muitos dos judeus castelhanos optariam por aqui ficar; outros regressariam à sua pátria de origem. Permaneceria, no entanto, entre as comunidades cristã-novas naturais de Portugal e de Castela, as mesmas características ancestrais:

- Mobilidade constante, dentro e fora do reino, tendo a melhor fugir à Inquisição e a alcançar outras paragens, onde pudessem voltar ao judaísmo;

- permanência dos cruzamentos familiares entre os membros de aquém e além fronteira.

Como aspecto novo, encontramos agora o acesso fácil à universidades, onde se destacam Coimbra e Salamanca, aos cargos municipais, aos de administração central e aos eclesiásticos. Tudo isto os tornava prestigiados e poderosos pelas relações com a nobreza, a Igreja e a corte. $O$ "statu quo", odiado pelos cristãos iria permanecer na minoria, ja não judaica, mas cristã nova.

A importância da presença castelhana entre esta minoria seria marcada pela vivência dos ideais messiânicos que iriam fazer dos cristãos novos de origem castelhana as primeiras vitimas da Inquisição portuguesa. 


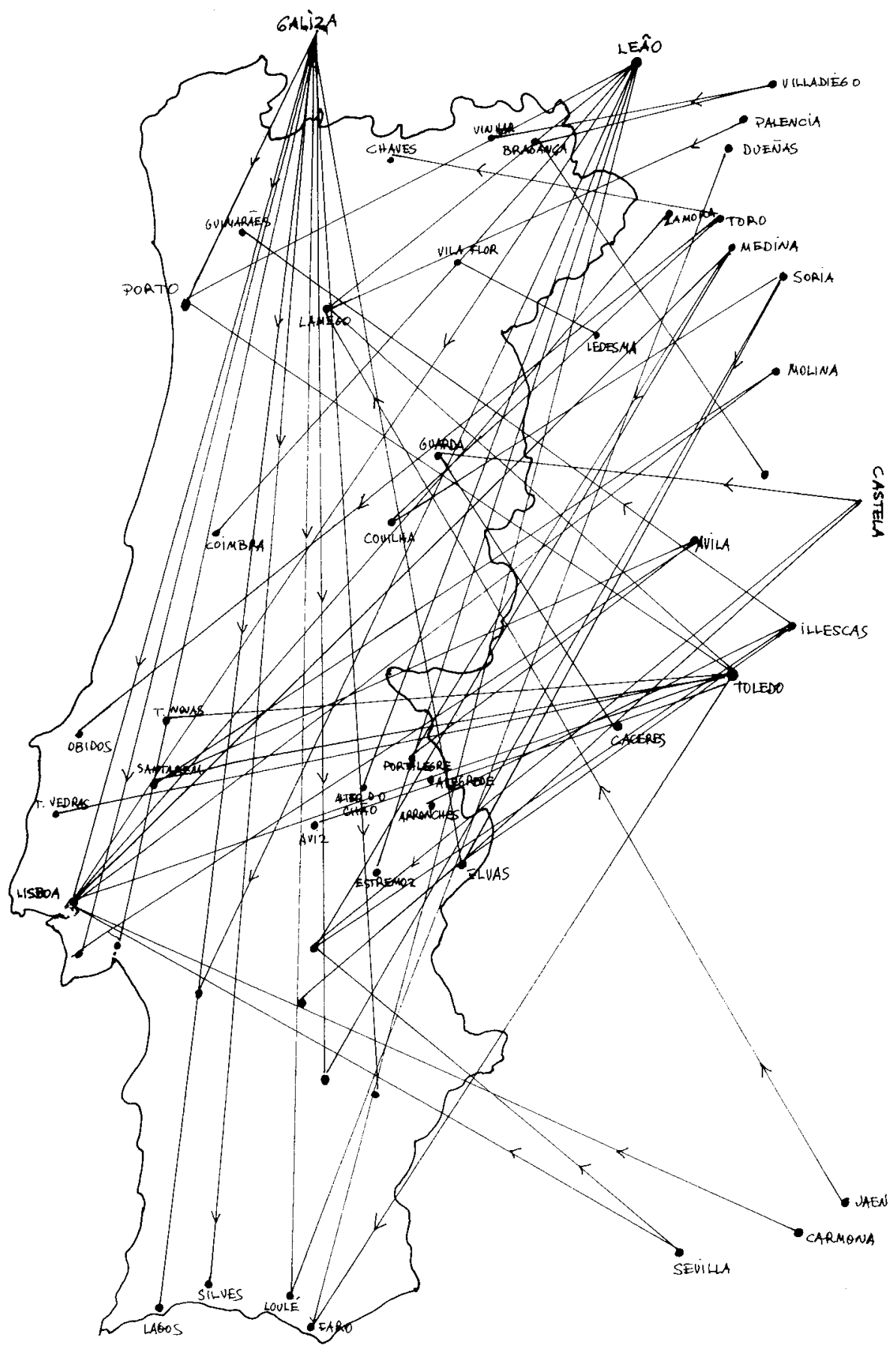

No 1.- Imjgracäo de judeus castelhanos, durante a

1. metade do séculoxv. 


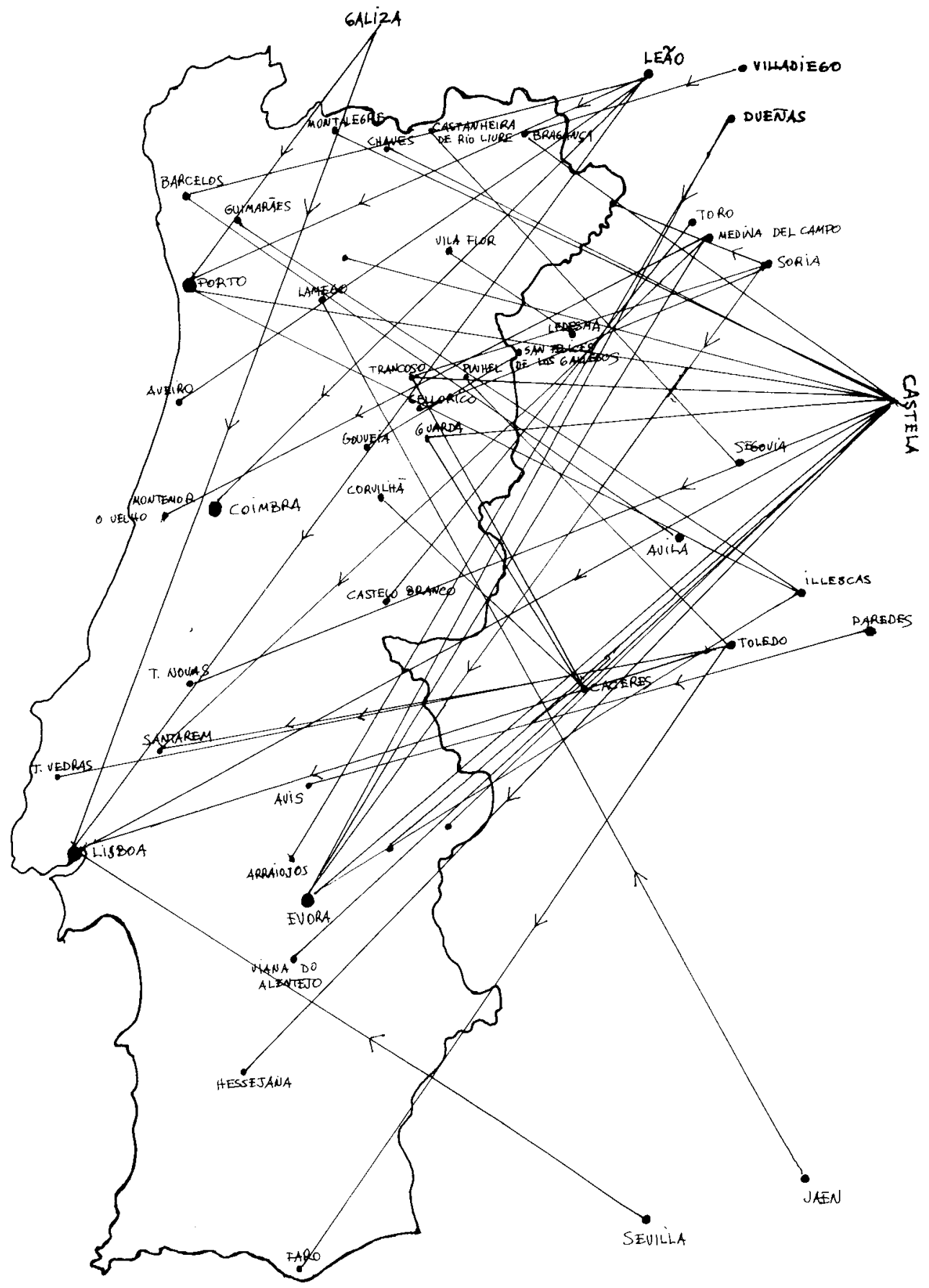

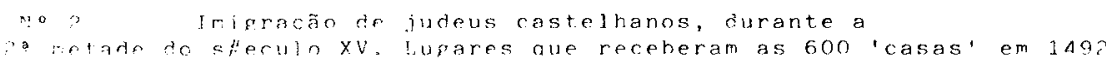




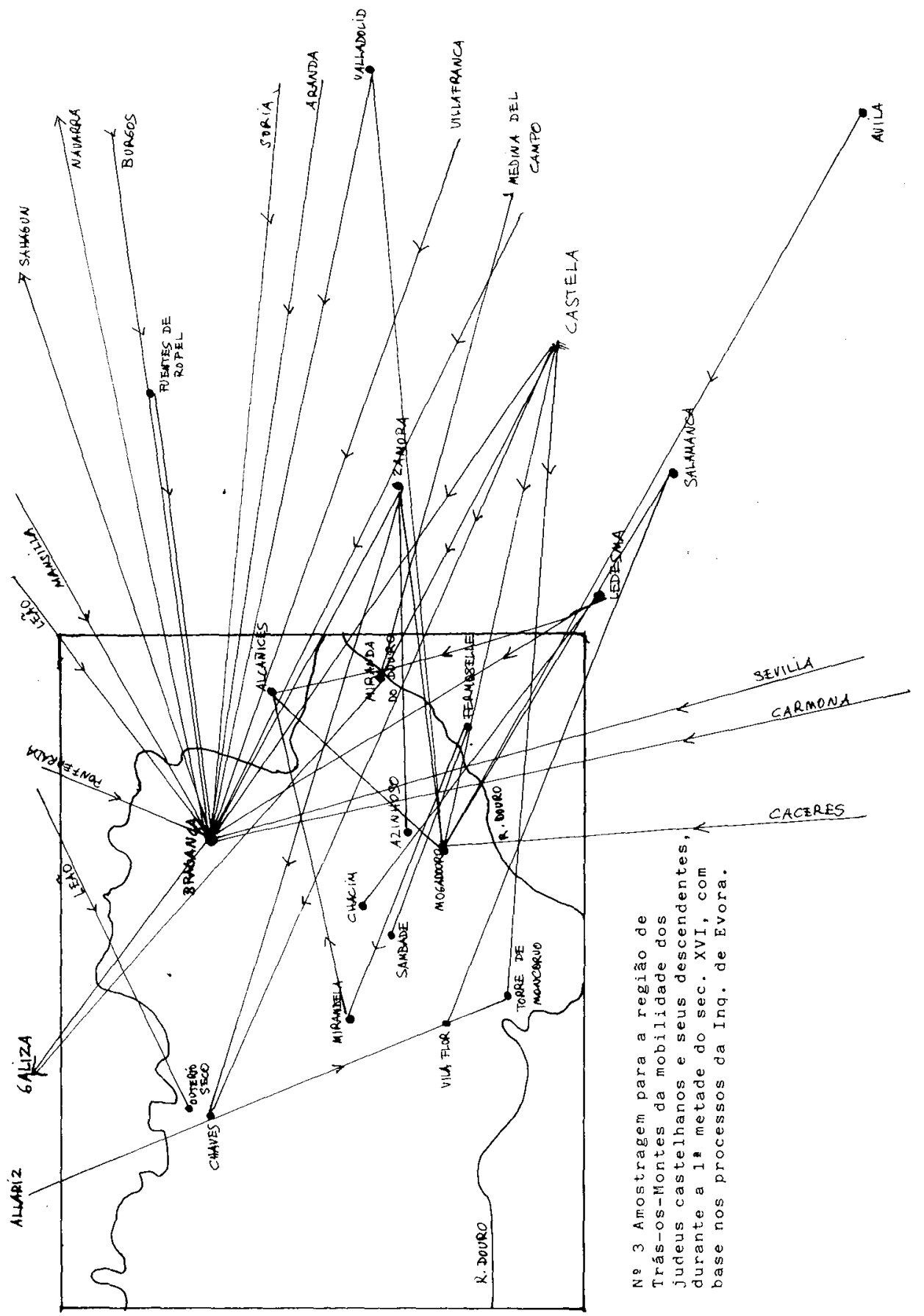





\section{NOTAS}

(1) Veja-se: AMADA LÓPEZ DE MENESES, «Una consecuencia de la peste negra en Cataluña: el pogrom de 1348», in Sefarad, Madrid 1959. vol. 19, pgs. $92-131$ e 321-364, entre outros.

(2) J. AMADOR DE LOS RÍOS, Historia social, política y religiosa de los judíos de España y Portugal, eds. Aguilar, 2. ${ }^{\text {a }}$ ed., Madrid 1973, pgs. 456-550.

(3) MARÍA JOSÉ PIMENTA FERRO TAVARES, Os judeus em Portugal no século XV. Universidade Nova de Lisboa, Lisboa 1982, vol. I, cap. VII, pgs. 418-430.

(4) Ibidem, pgs. 400-404.

(5) AMADOR DE LOS RIOS, ob. cit., pgs. 526-527.

(6) MARÍA JOSÉ FERRO TAVARES, ob. cit. pg. 421.

(7) Ordenaçōes Afonsinas, Coimbra 1792, liv. It, tit. 77, pgs. 457-460.

(8) Ibidem

(9) Ibidem, tit. 94, pgs. 514-519.

(10) Sobre este asunto, veja-se: MARÍA JOSÉ FERRO TAVARES, ob. cit., pgs. $432-433$.

(11) A. N. T. T., Reis, liv. 1, fis. 85-92; Monumenta Henricina, Coimbra 1964, vol. VI, pgs. 108-132; MARÍA JOSÉ FERRO TAVARES, ob. cit., pg. 312.

(12) B. NETANYAHU, Don Isaac Abravanel, statesman and philosopher, $3 .^{a}$ ed., Filadélfia 1972, pgs. 5-6 e 266-267, notas 12 a 14; Y. BAER, A history of the jews in christian Spain, Filadélfia 1966, vol. I, pg. 378 e vol. II, pg. 93.

(13) «Ya» aparece-nos na documentação sem qualquer abreviatura e exclusivamente aplicado aos Abravanéis. Poder-se-ia pensar numa forma abreviada de Jacob.

(14) A. N. T. T. Chancelaria de D. Afonso V, liv. 3, fls. 86v. -87 e Estremadura, liv. 8, fls. 299 300 , respectivamente.

(15) Ibidem, Chancelaria de D. Afonso $V$, liv. 2, fl. $76 \mathrm{v}$.

(16) Encyclopedia Judaica, Jerusalem 1971, vol. il, pg. 103.

(17) Henrique Fernandes Abravanel e Inês Fernandes, sua mulher, eram sobrinhos de Luna Abravanel, que em cristā se chamaria Leonor Fernandes (A. N. T. T., Chancelaria de D. Manuel, liv. 4, fl. 25; N. A. 318, fl. 23; Corpo Cronológico parte 1. ${ }^{\mathrm{a}}, \mathrm{m} .10, \mathrm{n} .{ }^{\circ}$ 165. Pela mesma altura, morava igualmente em Lisboa, Álvaro Fernandes Abravanel (Ibidem, Corpo Cronologico, parte $3{ }^{a}, \mathrm{~m} .4$, doc. 20 )

(18) Ibidem, Chancelaria de $D$. Afonso $V$, liv. 15, fls. $174 \mathrm{v}$. e $38 \mathrm{v}$., respectivamente.

(19) Ibidem, liv, 9, fl. 92v, e liv. 26, fls. 1-5; MARÍA JOSE P. FERRO TAVARES, ob. cit., vol. II, INIC 1984, pgs. 773-775.

(20) A. N. T. T., Chanceleria de D. Afonso V, liv. 32, fl. 38v

(21) Ibidem, liv. 32 , fls. $77-77 \mathrm{~V}$.

(22) Ibidem, liv. 4, fl. 14.

(23) Ibidem, liv. 15, fls. 38v,-39. 
(24) Ibidem, liv. 9, fl. 92v.

(25) Ibidem, liv. 33, fl. 182v.

(26) Ibidem, liv. 14, fls. 10v.-11; Estremadura, liv. 5, fl. 94v.

(27) A. TEIXEIRA DE ARAGÃO, Descripção geral e histórica das moedas cunhadas em nome dos reis, regentes e governadores de Portugal, 2. ${ }^{a}$ ed., Porto 1964, vol. I, pgs. 374-381.

(28) VIRGÍNIA RAU, "Alguns estudantes e eruditos portugueses em Itália no século XV", in Do Tempo e da História, IAC, Lisboa 1972, vol. V, pgs. 87-88.

(29) A. N. T. T., Chancelaria de D. Afonso V, liv. 3, fls. 86v. -87 ; Extras, fls. $69 \mathrm{v} .70$ e $119 \mathrm{v} .120$

(30) Ibidem, Chancelaria de D. João II, liv. 6, fls. 133v.-135.

(31) Ibidem, Corpo Cronológico, parte 1. ${ }^{a}, \mathrm{~m} .10,{ }^{\circ}{ }^{\circ} 165$.

(32) Ibidem

(33) Ibidem, Chancelaria de D. João II, liv. 21, fls. 39v. -40

(34) Ver nota 31.

(35) Ibidem, Chancelaria de D. Afonso V, liv. 1, fl. 16v.

(36) Ibidem, liv. 6, fl. 95.

(37) A. BRAAMCAMP FREIRE, «As conspiraçãos no reinado de D. João $1 \mathrm{l}$, Archivo Historico Portuguez, vol. II, docs. . $^{\circ} 4,6$ e 15 .

(38) Ibidem, doc. n. ${ }^{\circ} 6$, pg. 32.

(39) GARCÍA DE RESENDE, Cancioneiro Geral, Coimbra, Imprensa da Universidade 1910, vol. I, pgs. 62-63. (Os sublinhados são da nossa responsabilidada e identificam Samuel e Isaac Abravanel).

(40) Ver mapa n. ${ }^{\circ} 1$.

(41) A. N. T. T., Chancelaria de D. Afonso V, liv. 27, fl. 155.

(42) Ibidem, liv. 34, fl. 64v.

(43) Ibidem, liv. 1, fl. 43.

(44) Ibidem, liv. 14, fl. 2.

(45) Ibidem, liv. 32, fl. 63.

(46) Ibidem, liv. 9, fl. 94; liv. 36, fl. 196v.

(47) Ibidem, liv. 8, fl. 109.

(48) Ibidem, liv. 9, fl. 110v.

(49) Ibidem, Chacelaria de D. João II, liv. 25, fl. 66.

(50) Ibidem, liv. 16, fl. 115v.

(51) Ibidem, liv. 1, fl. 48.

(52) Registro General del Sello, Valladolid 1950, vol. I, n. ${ }^{\circ} 886, \mathrm{pg} .109 ;$ Records of the trials of Spanish Inquisition in Ciudad Real, ed. H. Beinart, Jerusalem 1985, vol. IV, pags. 50, $53,61,63,68$, etc.

(53) Porto, Gabinete de História de Cidade, Vereações, liv. 5, fls. 9v.-10

(54) Porto, Gabinete de História de Cidade, Vereações, liv. 5, fls. 99-100; MARÍA JOSÉ FE. RRO TAVARES, ob. cit., vol. 1, pg. 479, nota 366.

(55) Ibidem

(56) Porto, Gabinete de História de Cidade, Vereaçōes, liv. 5, fl. 107v.

(57) Ibidem, fls. 111v.-111v.

(58) RUI DE PINA, Chroniqua del rey dom Joham II, Coimbra 1950, pgs. 79-80; GARCIA DE RESENDE, Crónica de dom João /l, Imprensa Nacional-Casa da Moeda, Lisboa 1973, pgs. 101-102.

(59) A. N. T. T., Chancelaria de D. João II, liv. 15, fls. 36v. e 42.

(60) Lx., A. H. C. M., Livro 2. ${ }^{\circ}$ de D. João II, fl. 69.

(61) Livro das Posturas Antigas, Câmara Municipal de Lisboa, Lisboa 1974, pgs. 172-173.

(62) Ibidem, pgs. 173-175; MARIA JOSÉ FERRO TAVARES, ob. cit., vol. I, pg. 481, nota 378.

(63) MARIA JOSÉ FERRO TAVARES, ob. cit., pg. 447.

(64) L. SUÁREZ FERNÁNDEZ, Documentos acerca de la expulsión de los judíos, Valladolid 1964, pgs. 402-403, 418, 500-502.

(65) Ibidem, pgs. $452-453$. 
(66) Ibidem, pgs. 464-465.

(67) Ibidem, pgs. 505-506.

(68) RUI DE PINA, ob. cit., pgs. 179-183.

(69) GARCÍA DE RESENDE, ob. cit., pgs. 238-240.

(70) DAMIÃO DE GÓIS, Crónica do felicissimo rei D. Manuel, Coimbra 1949, pg. 23.

(71) Cit. por J. LÚCIO DE AZEVEDO, História dos cristãos novos portugueses, 2. a ed., Clássica editora, Lisboa 1975, pg. 21.

(72) DAMIĀO DE GÓlS, ob. cit., pg. 23.

(73) MARÍA JOSÉ FERRO TAVARES, ob. cit, pg. 253.

(74) ANDRÉS BERNALDEZ, Historia de los Reyes Católicos D. Fernando y D. ${ }^{a}$ Isabel. Crónica inédita del siglo XV, Granada 1856, vol. I, pg. 255; ALONSO DE SANTA CRUZ, Crónica de los Reyes Católicos, ed. Juan Mata Carriazo, Sevilha 1951, vol, I, pg. 661.

(75) I. ABOAB, Nomologia, Amesterdam 1629, pg. 322.

(76) ALONSO DE SANTA CRUZ, ob. cit, pg. 61; A. BERNALDEZ, ob. cit. pg. 255.

(77) SUÁREZ FERNÁNDEZ, ob. cit., pgs. 500-502 e 452-453, 424-425, 418-419, 402-403.

(78) Ibidem, pg. 402.

(79) A. BRAAMCAMP FREIRE, "Cartas de quitação del Rei D. Manuel» in Archivo Historico Portuguez, Lisboa 1904, vol. II, pg. 79.

(80) Ibidem, vol. III, pg. 472.

(81) Ibidem, pg. 315.

(82) MARÍA JOSÉ FERRO TAVARES, ob. cit., pgs. 253-257.

(83) ÉVORA, A. D., Livro 3 de Originais, fl. 214.

(84) Ibidem, fl. 207.

(85) A. N. T. T., Chancelaria de D. Manuel, liv. 32, fl. 99.

(86) Ibidem, Corpo Cronológico, parte $1, m .2, n .{ }^{\circ} 9$.

(87) A. BERNÁLDEZ, ob. cit., pg. 258.

(88) ÉVORA, A.D., Livro 3 de Originais, fis. 205-206v.

(89) GARCIA DE RESENDE, ob. cit., pgs. 253-254; RUI DE PINA, ob. cit. pgs. 187-188; I. ABOAB, ob. cit., pgs. 322-323 e 331 . 504.

(90) J. da SILVA MARQUES, Descobrimientos Portugueses, IAC, Lisboa 1971, vol. III, pg.

(91) Ibidem, pg. 510.

(92) I. N. T. T., Chancelaria de D. Manuel, liv. 40, fl. 32v.

(93) Lx., A. H. C. M., Livro 3 de D. João II, doc. n. ${ }^{\circ} 52$.

(94) Ibidem, doc. n. ${ }^{\circ} 61$

(95) Ibidem, doc. n. ${ }^{\circ} 62$

(96) A. N. T. T., Chancelaria de D. Manuel, liv. 26, fls. $27 \mathrm{~V} .-28$ e $64 \mathrm{v}$.

(97) Ibidem, liv. 32, fl. 108v.

(98) SUÁREZ FERNÁNDEZ, ob. cit., pg. 509.

(99) I. ABOAB, ob. cit., pgs. 321-322.

(100) M. GASPAR REMIRO, Los cronistas hispano-judíos, Granada 1920, pg. 36.

(101) A. N. T. T., Corpo Cronológico, parte 1, m. 2, n. ${ }^{\circ} 18$

(102) SUÁREZ FERNÁNDEZ, ob. cit. pgs. 487-489 e 526-527.

(103) Ibidem, pgs. 504-505.

(104) Ibidem, pgs. 520-521.

(105) Ibidem, pg. 528.

(106) R. G. del Sello, vol. X, pgs. 524-525.

(107) MARIA JOSÉ FERRO TAVARES, ob. cit, pgs. 486-487.

(108) A. N. T. T., Ordem de Cristo, B-26-55.

(109) Ibidem, Chancelaria de D. Manuel, liv. 16, fl. 108 v.

(110) Ibidem, liv. 1, fl. 57v. 
(111) Ibidem, Inquisição de Évora, $\mathrm{n}^{\circ} 6117$. Todas estas anotações pertencem a dois trabalhos que tenho em preparação, um deles em fase adiantada de redacção, um deles em fase adiantada de redacção: Os cristãos novos de Trás-os-Montes e Os cristãos novos em Portugal no século XVI.

(112) Ibidem, n. ${ }^{\circ} 1720$

(113) Ibidem, $n .{ }^{\circ} 2149,3738,1720,7726,6051,8612$; Inq. de Lisboa, n. ${ }^{\circ} 8612$. Os processos de ambos desapareceram.

(114) Ibidem, Inq. de Evora, n. ${ }^{\circ} 6051$

(115) Ibidem, n. ${ }^{\circ} 8612$

(116) Ibidem, Inq. de Lisboa, n. ${ }^{\circ} 2716$

(117) Ibidem, Inq. de Évora, n. ${ }^{\circ} 8612$ e 8447

(118) Ibidem, n. ${ }^{\circ} 8612$

(119) Ibidem, n. ${ }^{\circ} 6051$

(120) Ibidem, n. ${ }^{\circ} 2853$

(121) Ibidem, n. ${ }^{\circ} 8612$

(122) Ibidem, n. ${ }^{\circ} 4695$

(123) Ibidem, n. ${ }^{\circ} 6122$

(124) Ibidem, n. ${ }^{\circ} 5992$

(125) Ibidem, n. ${ }^{\circ} 7951$

(126) J. RODRÍGUEZ FERNÁNDEZ, La juderia de la ciudad de León, Leão 1969, pgs. 34-35.

(127) MARIA JOSÉ FERRO TAVARES, ob. cit. pgs. 369-370; As Gavetas da Torre do Tombo, Lisboa 1970, vol. X, pág. 359. 